\title{
Elevation of PTPN1 promoter methylation is a significant risk factor of type 2 diabetes in the Chinese population
}

\author{
QING HUANG $^{1 *}$, LIYUAN HAN ${ }^{2 *}$, YANFEN LIU $^{2}$, CHANGYI WANG $^{3}$, DONGHUI DUAN $^{2}$, \\ NANJIA LU ${ }^{2}$, KAIYUE WANG ${ }^{2}$, LU ZHANG $^{2}$, KAIBO GU $^{2}$, SHIWEI DUAN ${ }^{2}$ and YIFENG MAI ${ }^{1}$ \\ ${ }^{1}$ The Affiliated Hospital of Ningbo University School of Medicine, Ningbo, Zhejiang $315020 ;{ }^{2}$ Genetics Center, \\ School of Medicine, Ningbo University, Ningbo, Zhejiang 315211; ${ }^{3}$ Department of Chronic Disease Prevention and \\ Control, Shenzhen Nanshan Center for Chronic Disease Control, Shenzhen, Guangdong 518000, P.R. China
}

Received March 16, 2016; Accepted March 6, 2017

DOI: $10.3892 /$ etm.2017.4924

\begin{abstract}
The present study aimed to investigate the contribution of DNA methylation of the protein tyrosine phosphatase, non-receptor type 1 (PTPN1) gene to the susceptibility to type 2 diabetes (T2D). Peripheral blood mononuclear cells (PBMCs) were collected from 97 patients with T2D and 97 age- and gender-matched controls. DNA methylation of the PTPN1 gene promoter was evaluated by bisulfite pyrosequencing. Independent sample t-tests were used to compare the differences in the PTPN1 promoter and other phenotypes between the patients with T2D and the controls. The results indicated a significant correlation between PTPN1 promoter methylation and the risk of T2D. Additionally, a breakdown analysis by gender revealed that PTPN1 methylation was associated with an increased risk of T2D in females. Furthermore, low-density lipoprotein $(\mathrm{r}=-0.183, \mathrm{P}=0.046)$ and total cholesterol $(\mathrm{r}=-0.310$, $\mathrm{P}=0.001)$ were inversely associated with PTPN1 methylation in females. In conclusion, the results indicate that elevated PTPN1 promoter methylation is a risk factor for T2D in the female Chinese population.
\end{abstract}

Correspondence to: Dr Yifeng Mai, The Affiliated Hospital of Ningbo University School of Medicine, 247 Renmin Road, Ningbo, Zhejiang 315020, P.R. China

E-mail: nbmyf@msn.com

Dr Shiwei Duan, Genetics Center, School of Medicine, Ningbo University, 818 Fenghua Road, Ningbo, Zhejiang 315211, P.R. China E-mail: duanshiwei@nbu.edu.cn

*Contributed equally

Abbreviations: PTPN1, protein tyrosine phosphatase, non-receptor type 1; T2D, type 2 diabetes; PBMCs, peripheral blood mononuclear cells; PTP1B, protein-tyrosine phosphatase 1B; IR, insulin receptor; TG, triglyceride; TC, total cholesterol; LDL, low-density lipoprotein; UA, uric acid; CRE, creatinine

Key words: methylation, protein tyrosine phosphatase, non-receptor type 1 , promoter, type 2 diabetes

\section{Introduction}

Type 2 diabetes (T2D), which accounts for $>90 \%$ of cases of diabetes, is a complex metabolic disorder, and its prevalence is increasing worldwide. It is estimated by the International Diabetes Federation that the number of patients with T2D will reach 592 million in 2035 (1). Additionally, the high morbidity rate of T2D primarily results from the lack of understanding its pathogenic mechanisms.

Genes, environmental factors and their interactions are hypothesized to contribute to the development of T2D (2). Furthermore, a large number of susceptible genetic loci have been identified by genome wide association studies $(3,4)$. Numerous environmental factors affecting T2D have also been established, including diet (5) and an unhealthy lifestyle (6). However, these observations only explain a small portion of the susceptibility to T2D (7).

Epigenetic modifications are heritable changes in gene function without any change in the nucleotide sequence. The functions of epigenetic modifications on diabetes have been recognized, such as on the origin and progression of diabetes (8-11). Primarily, DNA methylation, which is one of the most studied epigenetic modifications, is affected by several environmental factors, such as the diet (12), hyperglycemia (13) and hyperlipemia (5). There is that aberrant DNA methylation of pancreatic and duodenal homeobox 1 (13), monocyte chemotactic protein 1 (14), B-cell lymphoma/leukemia (BCL11A) (15) and glucokinase $(G C K)(16)$ genes are associated with the risk of T2D. Furthermore, aberrant DNA methylation can alter gene expression (17). Given these observations, it appears that DNA methylation research may be useful for revealing the pathogenesis of T2D.

Insulin and leptin signaling are important in mammals (18-22). As an insulin signaling pathway gene, the protein tyrosine phosphatase, non-receptor type 1 (PTPN1) gene encodes the protein-tyrosine phosphatase 1B (PTP1B) protein (23). Additionally, overexpression of PTP1B hinders the insulin-signaling pathway by decreasing the phosphorylation of the insulin receptor (IR) and/or insulin receptor substrate 1 (20). Conversely, in PTP1B-deficient mice, insulin sensitivity is enhanced, and the phosphorylation of the IR in the liver and muscle is increased and prolonged $(24,25)$. PTP1B 
also attenuates leptin action through binding and dephosphorylating the Janus kinase 2 -a receptor of leptin $(21,22)$. It is noteworthy that small-molecule inhibitors of PTP1B have gained much progression in the treatment of T2D (26-28).

In the present study, methylation of the PTPN1 promoter was hypothesized to be capable of altering gene expression. Furthermore, it is expected that testing the association of PTPN1 methylation with the risk of T2D may provide further information concerning the pathogenic mechanism of T2D.

\section{Materials and methods}

Sample collection. A total of 97 T2D cases and 97 age- and gender-matched controls were recruited from 16 Community Health Service Centers, which were affiliated to the Shenzhen Nanshan Center for Chronic Disease Control (Shenzhen, China). The participants were between 50 and 70 years old. The body mass index (BMI) was calculated using the following formula: BMI=weight $(\mathrm{kg}) /$ height $\left(\mathrm{m}^{2}\right)$. Furthermore, T2D was diagnosed according to the 1999 World Health Organization standard, which defines diabetes as a fasting plasma glucose level $\geq 7.0 \mathrm{mmol} / \mathrm{l}$, a $2 \mathrm{~h}$ oral glucose tolerance test level $\geq 11.1 \mathrm{mmol} / 1$, or patients receiving antidiabetic medication treatment (29). Additionally, the subjects did not have a history of hypertension, coronary heart disease, drug abuse or other serious diseases. The study was approved by the Ethics Committees of the Affiliated Hospital of Ningbo University and Shenzhen Nanshan Center for Chronic Disease Control, and all participants provided written informed consent forms.

PBMC isolation and DNA extraction. Blood samples were collected in tubes containing EDTA and PBMCs were isolated using Ficoll-Paque (Histopaque 1077; Sigma-Aldrich; Merck KGaA, Darmstadt, Germany) by means of density gradient centrifugation $(1,000 \mathrm{x} \mathrm{g}$ for $30 \mathrm{~min}$ at room temperature). Then the PBMCs were washed twice with PBS to prepare for DNA extraction. Human genomic DNA extraction and quantification were performed as described previously (30).

Biochemical and bisulfite pyrosequencing. Plasma triglyceride (TG), total cholesterol (TC), low-density lipoprotein (LDL) levels, glucose concentration, creatinine (CRE) and uric acid (UA) were all measured using a CX7 Analyzer (Beckman Coulter, Inc., Brea, CA, USA) according to the manufacturer's protocol. The PTPN1 methylation level was determined using pyrosequencing technology (Pyromark Gold Q24 Reagents; Qiagen China Co., Ltd., Shanghai, China). The primer sequences used were: 5'-biotin-TAGGGGTAGGGGATT GTA-3' (forward) and 5'-CTCCTTTTCCATCTCCATA-3' (reverse), and 5'-TTTTCCATCTCCATAA-3' (sequencing primer). All oligomers were synthesized by Sangon Biotech Co., Ltd. (Shanghai, China). Detailed information on the methylation assay has been provided in previous studies $(15,16)$.

Statistical analysis. Independent sample t-test was used to compare the differences of continuous variables between the patients with T2D and controls. Pearson's correlation analysis was used to analyze the association between PTPNI methylation and metabolic characteristics of subjects. $P<0.05$ was considered to indicate a statistically significant difference.
All statistical analyses were performed using PASW statistics version 18.0 software (SPSS, Inc., Chicago, IL, USA).

\section{Results}

Correlation analysis of the cytosine-guanine dinucleotide site (CpG) methylation of PTPN1 with T2D. As shown in Fig. 1, the bisulfite pyrosequencing assay was performed on a fragment (chr20: 49126618-49127435) in the promoter region of the PTPN1 gene. A total of eight CpG sites were evaluated in order to explore their association with the risk of T2D. The methylation levels of all eight $\mathrm{CpG}$ loci showed a significant strong correlation (mean $\mathrm{r}>0.47, \mathrm{P}<0.001$ ).

Correlation between PTPN1 methylation and T2D. As shown in Table I, the methylation levels of the eight CpGs were significantly elevated in T2D cases compared with the controls (CpG1, P=0.001; CpG2, P=0.002; CpG3, P=0.001; CpG4, $\mathrm{P}=0.003 ; \mathrm{CpG}$, $\mathrm{P}=0.007$; $\mathrm{CpG6}, \mathrm{P}=0.001 ; \mathrm{CpG} 7, \mathrm{P}=0.036$; CpG8, $\mathrm{P}=0.001)$. Increased levels of mean PTPN1 (CpG1-8) methylation were also observed in $\mathrm{T} 2 \mathrm{D}$ cases $(\mathrm{P}=0.001$; Fig. 2). Further gender breakdown analysis demonstrated that the methylation levels of the $\mathrm{CpGs}(\mathrm{CpG1}-8)$ were significantly elevated in female T2D cases compared with female controls (all $\mathrm{P}<0.05$; Table I). However, no significant differences in PTPN1 methylation between male T2D cases and male controls were identified (all P>0.05; Table I).

Clinical characteristics of the subjects. The results of the present study indicate that TG $(\mathrm{P}=0.018)$ and CRE $\left(\mathrm{P}=6.00 \times 10^{-3}\right)$ levels are significantly different between the patients with T2D and the controls for all subjects (Table II). While the levels of TG $(\mathrm{P}=0.002)$, LDL $(\mathrm{P}=0.040)$ and UA $(\mathrm{P}=0.037)$ were significantly different between the cases and controls in females, the CRE levels were significantly different between the cases and controls in males $(\mathrm{P}=0.002$; Table II). Further correlation analyses between clinical parameters and PTPN1 methylation were also conducted. Notably, significant correlations of LDL $(\mathrm{r}=-0.310, \mathrm{P}=0.001)$ and $\mathrm{TC}$ $(\mathrm{r}=-0.183, \mathrm{P}=0.046)$ concentration with PTPN1 methylation were observed only in females, and age $(r=0.275, P=0.017)$ exhibited a significant correlation with PTPN1 methylation only in male T2D patients (Fig. 3). Furthermore, no significant correlations between other phenotypes and PTPN1 methylation were identified $(\mathrm{P}>0.05)$.

\section{Discussion}

DNA methylation is a common epigenetic modification, and increasing evidence suggests that it is important in T2D (15,16,31). The goal of the present study was to evaluate the contribution of PTPN1 promoter methylation to the risk of T2D. The results of the present study revealed that T2D cases have a significantly higher methylation level in the PTPN1 promoter compared with healthy controls, particularly in females. To the best of our knowledge, this is the first study to investigate the association of PTPN1 promoter methylation with T2D in humans.

PTP1B is a key modulator of energy metabolism, involved in insulin (20), leptin (21) and other signal transduction 


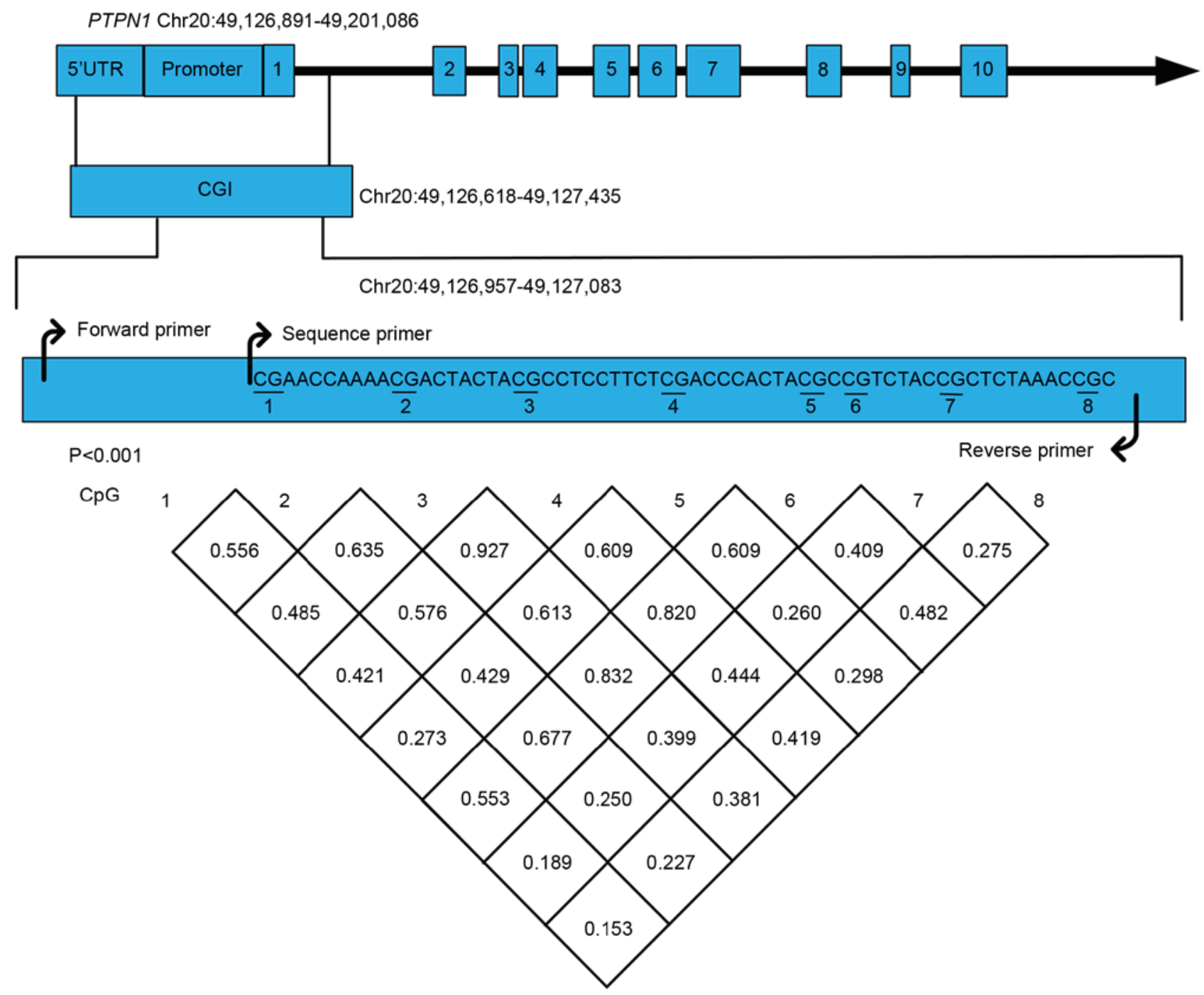

Figure 1. Pairwise correlation among eight methylated cytosine-guanine dinucleotide sites in the PTPN1 gene promoter. PTPN1, protein tyrosine phosphatase, non-receptor type 1; CpG, cytosine-guanine dinucleotide site; UTR, untranslated region.

pathways (32). Insulin resistance is the core mechanism in the development of T2D (20). Previous studies in mice reveal that PTP1B-deficiency increases energy expenditure, tissue-specific insulin sensitivity, obesity resistance $(20,24,25)$ and leptin signaling in the hypothalamus (33). Furthermore, PTP1B antisense oligonucleotide has been shown to improve insulin sensitivity in the liver and fat in diabetic mouse models (20). PTPN1 1484insG variation contributes to insulin resistance by upregulating PTPN1 expression (34). Additionally, PTPN1 polymorphisms have been shown to be significant risk factors for T2D (35). Murashov et al (36) demonstrated that the alteration of mouse PTPN1 gene expression in the skeletal muscle of offspring may occur as a consequence of paternal long-term exercise, resulting in metabolic disorders, including lower energy expenditure, increased obesity risk, impaired glucose tolerance and elevated insulin levels in the offspring. The present study revealed that elevated PTPN1 methylation is associated with T2D, providing new information useful for elaborating the role of this gene in the pathogenesis of T2D.

Promoter hypermethylation often downregulates gene transcription (37). Furthermore, DNA methylation has been shown to be important in the development of T2D $(38,39)$.
CpG sites in the mouse Ins 2 and human INS promoters can suppress insulin promoter-driven reporter gene activity, and thus regulate the insulin expression of pancreatic $\beta$ cells (39). Our previous studies have suggested that $\mathrm{CpG}$ island methylation of BCL11A and GCK is associated with the risk of T2D in the male Chinese population $(15,16)$. Furthermore, in the present study, PTPN1 gene methylation was found to predict the risk of T2D in the female Chinese population. Additionally, it may be hypothesized that PTPN1 methylation alters PTPN1 gene expression or PTP1B activity, and thus increases the risk of T2D. However, further studies on the mechanism associating PTPN1 methylation with T2D are required to support this hypothesis.

Previous studies have suggested that gender disparities are widely present in T2D and its complications $(15,16,40,41)$. Sex hormone imbalance has significant association with the high risk of T2D and concomitant complications (42). Sex hormones regulate the level of DNA methylation (43) and their induced epigenetic changes may increase or reduce the disease risk (44). Additionally, the X-chromosome methylation in islets is higher in females than in males (45). Also, sex-specific DNA methylation patterns have been identified 
Table I. Comparison of protein tyrosine phosphatase, non-receptor type 1 methylation levels (\%) between cases of T2D and controls.

\begin{tabular}{|c|c|c|c|}
\hline Characteristics & Controls & Cases & P-value \\
\hline \multicolumn{4}{|c|}{ All subjects, $n=194^{a}$} \\
\hline CpG1 & $12.00 \pm 9.03$ & $15.98 \pm 9.18$ & 0.001 \\
\hline $\mathrm{CpG} 2$ & $6.41 \pm 3.16$ & $8.68 \pm 4.48$ & 0.002 \\
\hline CpG3 & $5.57 \pm 1.88$ & $6.98 \pm 3.11$ & 0.001 \\
\hline CpG4 & $15.46 \pm 5.76$ & $18.87 \pm 8.09$ & 0.003 \\
\hline CpG5 & $6.23 \pm 1.75$ & $7.51 \pm 3.69$ & 0.007 \\
\hline CpG6 & $4.60 \pm 0.87$ & $5.21 \pm 1.24$ & 0.001 \\
\hline CpG7 & $4.84 \pm 1.39$ & $5.15 \pm 1.60$ & 0.036 \\
\hline CpG8 & $4.37 \pm 0.70$ & $4.89 \pm 0.76$ & 0.001 \\
\hline CpG mean & $7.43 \pm 2.37$ & $9.16 \pm 3.02$ & $1.34 \times 10^{-4}$ \\
\hline \multicolumn{4}{|l|}{ Female, $\mathrm{n}=120^{\mathrm{b}}$} \\
\hline CpG1 & $10.77 \pm 7.86$ & $16.57 \pm 9.33$ & 0.001 \\
\hline CpG2 & $5.92 \pm 2.14$ & $8.77 \pm 5.02$ & 0.001 \\
\hline CpG3 & $5.37 \pm 1.88$ & $6.78 \pm 3.06$ & 0.013 \\
\hline CpG4 & $14.80 \pm 5.73$ & $18.34 \pm 8.25$ & 0.021 \\
\hline CpG5 & $6.15 \pm 1.96$ & $7.18 \pm 2.03$ & 0.044 \\
\hline CpG6 & $4.51 \pm 0.92$ & $5.23 \pm 1.29$ & 0.006 \\
\hline CpG7 & $4.59 \pm 0.90$ & $5.07 \pm 0.94$ & 0.023 \\
\hline CpG8 & $4.26 \pm 0.76$ & $4.84 \pm 0.71$ & $1.00 \times 10^{-3}$ \\
\hline CpG mean & $7.05 \pm 2.15$ & $9.10 \pm 3.12$ & $4.82 \times 10^{-4}$ \\
\hline \multicolumn{4}{|l|}{ Male, $n=74^{c}$} \\
\hline CpG1 & $14.00 \pm 10.46$ & $15.02 \pm 8.96$ & 0.918 \\
\hline CpG2 & $7.20 \pm 4.25$ & $8.53 \pm 3.48$ & 0.570 \\
\hline CpG3 & $5.90 \pm 1.86$ & $7.29 \pm 3.21$ & 0.067 \\
\hline CpG4 & $16.51 \pm 5.74$ & $19.75 \pm 7.85$ & 0.072 \\
\hline CpG5 & $6.35 \pm 1.36$ & $8.06 \pm 5.40$ & 0.101 \\
\hline CpG6 & $4.74 \pm 0.78$ & $5.17 \pm 1.16$ & 0.128 \\
\hline CpG7 & $5.24 \pm 1.88$ & $5.28 \pm 2.32$ & 0.536 \\
\hline CpG8 & $4.54 \pm 0.58$ & $4.96 \pm 0.85$ & 0.436 \\
\hline CpG mean & $8.06 \pm 2.61$ & $9.26 \pm 2.89$ & 0.192 \\
\hline
\end{tabular}

${ }^{a}$ DNA methylation in the T2D controls and cases was adjusted for smoking, drinking, TG and CRE in all subjects. ${ }^{b} \mathrm{DNA}$ methylation in T2D controls and cases was adjusted for drinking, triglyceride, low-density lipoprotein and uric acid in females. ${ }^{\circ} \mathrm{DNA}$ methylation in T2D controls and cases was adjusted for drinking, smoking and creatinine in males. Results are expressed as the mean \pm standard deviation. CpGs, cytosine-guanine dinucleotide sites; T2D, type 2 diabetes.

in the blood (43), heart muscle (5) and liver (46). The present study indicates that promoter methylation of the PTPN1 gene may contribute to T2D susceptibility in females, which suggests that PTPN1 methylation may contribute to the risk of $\mathrm{T} 2 \mathrm{D}$ in females by a mechanism involving the regulatory effects of sex hormones.

Aberrant clinical phenotypes are indispensable contributors to the development of T2D. In the present study, PTPN1 methylation was found to be correlated with TC and LDL in females, although TC and LDL are not able to predict the risk of T2D. Furthermore, it is speculated that PTPN1 methylation may increase the risk for T2D by influencing TC and LDL metabolism in females.

The present study indicates that PTPN1 methylation is positively correlated with age in males. In addition to being observed in the peripheral blood, age-associated DNA methylation (47) has been detected in other human tissues, including the skeletal muscle (48), kidney (49) and brain (47). Additionally, age and environmental factors may exert an influence on the risk of diabetes by altering tissue-specific methylation of certain genes (50), and age-dependent gene hypermethylation has also been observed in human skeletal muscle (51).

However, the following limitations of the present study should be noted. First, the sample size calculation indicates that 194 patients will give $97.8 \%$ power at $\alpha=0.05$ to detect a mean difference in DNA methylation (standard deviation, $3.02 \%$ ) between T2D cases and controls. Further power analysis showed that there was $94.6 \%$ power for females and $41.8 \%$ power for males. Thus, the observations in the 
Table II. Characteristics of the subjects in the T2D case and control groups.

\begin{tabular}{|c|c|c|c|}
\hline Characteristics & Controls & Cases & P-value \\
\hline \multicolumn{4}{|c|}{ All subjects, $n=194$} \\
\hline Age (years) & $59.79 \pm 9.39$ & $59.79 \pm 9.39$ & 1.000 \\
\hline BMI $\left(\mathrm{kg} / \mathrm{m}^{2}\right)$ & $23.19 \pm 1.65$ & $23.19 \pm 1.61$ & 0.985 \\
\hline $\mathrm{TC}(\mathrm{mmol} / \mathrm{l})$ & $5.15 \pm 0.91$ & $5.21 \pm 1.25$ & 0.711 \\
\hline $\mathrm{TG}(\mathrm{mmol} / \mathrm{l})$ & $1.49 \pm 0.59$ & $2.26 \pm 2.89$ & $0.018^{\mathrm{d}}$ \\
\hline $\mathrm{LDL}(\mathrm{mmol} / \mathrm{l})$ & $3.22 \pm 0.80$ & $2.98 \pm 0.92$ & 0.053 \\
\hline $\mathrm{UA}(\mu \mathrm{mol} / \mathrm{l})$ & $332.90 \pm 88.57$ & $344.28 \pm 97.79$ & 0.400 \\
\hline $\mathrm{CRE}(\mu \mathrm{mol} / \mathrm{l})$ & $69.20 \pm 17.80$ & $77.19 \pm 24.28$ & $6.00 \times 10^{-3 \mathrm{~d}}$ \\
\hline \multicolumn{4}{|l|}{ Female, $n=120$} \\
\hline Age (years) & $60.07 \pm 8.64$ & $60.07 \pm 8.64$ & 1.000 \\
\hline $\mathrm{BMI}\left(\mathrm{kg} / \mathrm{m}^{2}\right)$ & $22.86 \pm 1.66$ & $22.98 \pm 1.61$ & 0.701 \\
\hline $\mathrm{TC}(\mathrm{mmol} / \mathrm{l})$ & $5.28 \pm 1.17$ & $5.41 \pm 0.87$ & 0.476 \\
\hline $\mathrm{TG}(\mathrm{mmol} / \mathrm{l})$ & $1.52 \pm 0.55$ & $2.42 \pm 2.20$ & $0.002^{\mathrm{a}}$ \\
\hline LDL (mmol/l) & $3.35 \pm 0.85$ & $3.01 \pm 0.96$ & 0.040 \\
\hline $\mathrm{UA}(\mu \mathrm{mol} / \mathrm{l})$ & $293.87 \pm 70.51$ & $325.18 \pm 90.79$ & 0.037 \\
\hline CRE $(\mu \mathrm{mol} / 1)$ & $63.77 \pm 19.07$ & $68.83 \pm 23.04$ & $0.084^{\mathrm{a}}$ \\
\hline \multicolumn{4}{|l|}{ Male, $n=74$} \\
\hline Age (years) & $59.35 \pm 10.60$ & $59.35 \pm 10.60$ & 1.000 \\
\hline BMI (kg/m²) & $23.72 \pm 1.51$ & $23.55 \pm 1.63$ & 0.633 \\
\hline $\mathrm{TC}(\mathrm{mmol} / \mathrm{l})$ & $4.74 \pm 0.82$ & $5.11 \pm 1.37$ & 0.162 \\
\hline TG (mmol/l) & $1.45 \pm 0.66$ & $1.99 \pm 3.78$ & $0.969^{\mathrm{a}}$ \\
\hline LDL (mmol/l) & $3.01 \pm 0.68$ & $2.93 \pm 0.88$ & 0.666 \\
\hline $\mathrm{UA}(\mu \mathrm{mol} / \mathrm{l})$ & $396.19 \pm 78.19$ & $375.24 \pm 101.96$ & 0.325 \\
\hline CRE $(\mu \mathrm{mol} / 1)$ & $78.00 \pm 10.95$ & $90.73 \pm 19.91$ & $0.002^{\mathrm{a}}$ \\
\hline
\end{tabular}

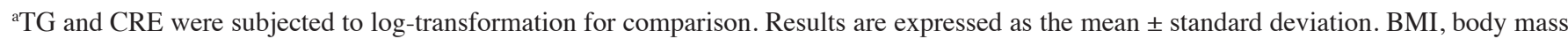
index; TC, total cholesterol; TG, triglyceride; LDL, low-density lipoprotein; UA, uric acid; CRE, creatinine; T2D, type 2 diabetes.

total samples were reliable; however, the negative results in the males may require confirmation using larger sample sizes in future studies. Secondly, the underlying molecular mechanism explaining why PTPN1 methylation increases the risk of T2D was not investigated in the present study. Thirdly, epigenetic differences are tissue-specific, and blood samples may not fully represent the contribution of PTPN1 to T2D in other tissues such as the pancreatic islets.

In conclusion, the present study demonstrates a significant correlation between elevated $\mathrm{CpG}$ methylation of PTPN1 and T2D in females, which may further help to clarify the pathogenesis of T2D. However, further studies with a larger sample size are required to elucidate the underlying mechanisms, as well as to explore the interactions between DNA methylation and environmental factors contributing to the susceptibility of T2D.

\section{Acknowledgements}

The present study was supported by the National Natural Science Foundation of China (grant no. 81402745), the Zhejiang Provincial Medical and Healthy Science and Technology Projects (grant no. 2013KYA228), the Ministry

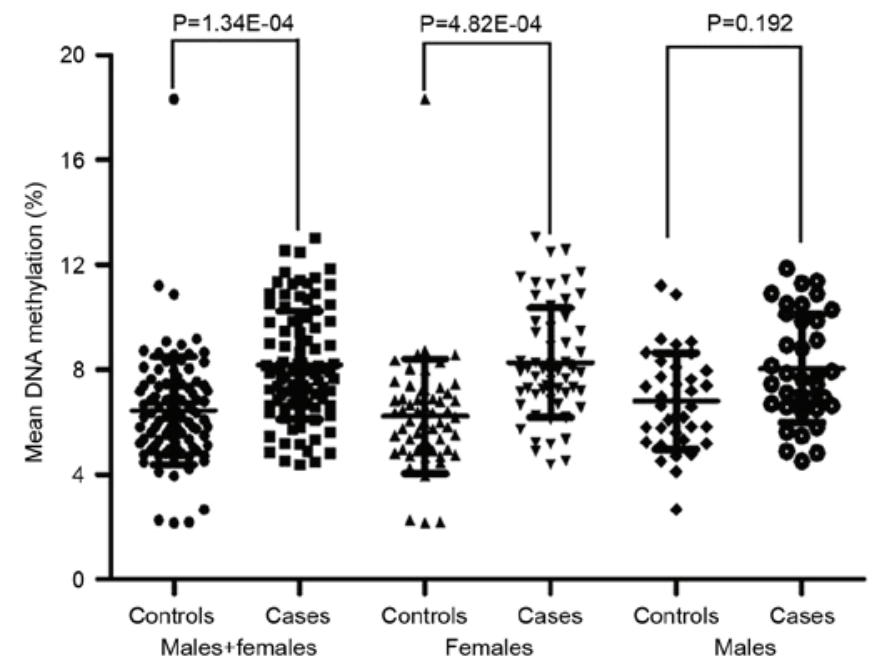

Figure 2. Comparison of the mean DNA methylation levels of the protein tyrosine phosphatase, non-receptor type 1 gene promoter between patients with type 2 diabetes and controls.

of Education, Humanities and Social Sciences project (grant no. 14YJC630046), the Natural Science Foundation of Ningbo 

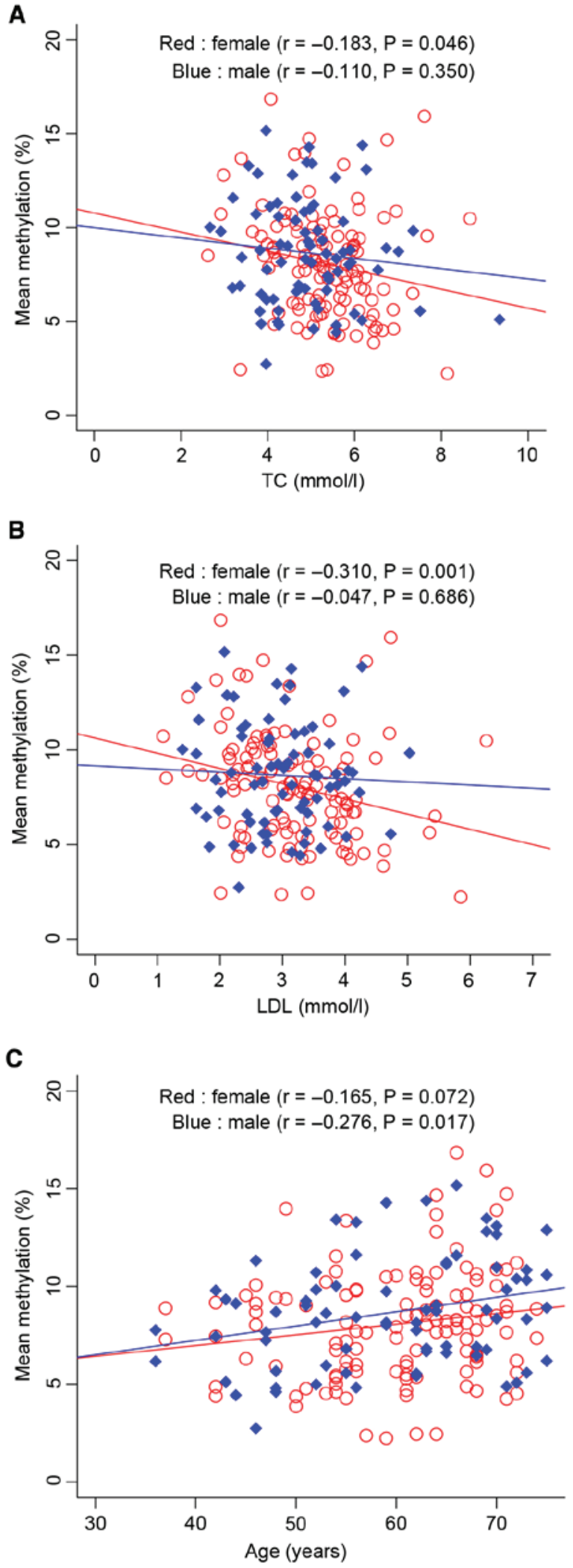

Figure 3. Correlation analyses between the mean protein tyrosine phosphatase, non-receptor type 1 DNA methylation and clinical phenotypes. Correlation analyses between (A) the mean PTPN1 DNA methylation and TC level, and (B) the mean PTPN1 DNA methylation and LDL level. TC, total cholesterol; LDL, low-density lipoprotein.

City (grant no. 2014A610268), the Natural Science Foundation of Zhejiang Province (grant no. LQ13H260002) and the K. C. Wong Magna Fund of Ningbo University.

\section{References}

1. International Diabetes Federation: Annual Report 2014. http://www.idf.org/sites/default/files/IDF-2014-Annual-Report-final. pdf. Accessed March 13, 2016.

2. Gu T, Horová E, Möllsten A, Seman NA, Falhammar H, Prazny M, Brismar K and Gu HF: IGF2BP2 and IGF2 genetic effects in diabetes and diabetic nephropathy. J Diabetes Complications 26: 393-398, 2012.

3. Drong AW, Lindgren CM and McCarthy MI: The genetic and epigenetic basis of type 2 diabetes and obesity. Clin Pharmacol Ther 92: 707-715, 2012.

4. Kwak SH, Kim SH, Cho YM, Go MJ, Cho YS, Choi SH, Moon MK, Jung HS, Shin HD, Kang HM, et al: A genome-wide association study of gestational diabetes mellitus in Korean women. Diabetes 61: 531-541, 2012.

5. Tobias DK, Hu FB, Chavarro J, Rosner B, Mozaffarian D and Zhang C: Healthful dietary patterns and type 2 diabetes mellitus risk among women with a history of gestational diabetes mellitus. Arch Intern Med 172: 1566-1572, 2012.

6. Wittmeier KD, Wicklow BA, Sellers EA, Griffith AT, Dean HJ and McGavock JM: Success with lifestyle monotherapy in youth with new-onset type 2 diabetes. Paediatr Child Health 17: 129-132, 2012.

7. Voight BF, Scott LJ, Steinthorsdottir V, Morris AP, Dina C, Welch RP, Zeggini E, Huth C, Aulchenko YS, Thorleifsson G, et al: Twelve type 2 diabetes susceptibility loci identified through large-scale association analysis. Nat Genet 42: 579-589, 2010.

8. Pinney SE and Simmons RA: Epigenetic mechanisms in the development of type 2 diabetes. Trends Endocrinol Metab 21: 223-229, 2010.

9. Pirola L, Balcerczyk A, Okabe J and El-Osta A: Epigenetic phenomena linked to diabetic complications. Nat Rev Endocrinol 6: 665-675, 2010.

10. Wren JD and Garner HR: Data-mining analysis suggests an epigenetic pathogenesis for type 2 diabetes. J Biomed Biotechnol 2005: 104-112, 2005.

11. Slomko H, Heo HJ and Einstein FH: Minireview: Epigenetics of obesity and diabetes in humans. Endocrinology 153: 1025-1030, 2012.

12. Jacobsen SC, Brøns C, Bork-Jensen J, Ribel-Madsen R, Yang B Lara E, Hall E, Calvanese V, Nilsson E, Jørgensen SW, et al: Effects of short-term high-fat overfeeding on genome-wide DNA methylation in the skeletal muscle of healthy young men. Diabetologia 55: 3341-3349, 2012.

13. Yang BT, Dayeh TA, Volkov PA, Kirkpatrick CL, Malmgren S, Jing X, Renström E, Wollheim CB, Nitert MD and Ling C: Increased DNA methylation and decreased expression of PDX-1 in pancreatic islets from patients with type 2 diabetes. Mol Endocrinol 26: 1203-1212, 2012.

14. Liu ZH, Chen LL, Deng XL, Song HJ, Liao YF, Zeng TS, Zheng $\mathrm{J}$ and Li HQ: Methylation status of CpG sites in the MCP-1 promoter is correlated to serum MCP-1 in Type 2 diabetes. J Endocrinol Invest 35: 585-589, 2012.

15. Tang L, Wang L, Ye H, Xu X, Hong Q, Wang H, Xu L, Bu S, Zhang L, Cheng J, et al: BCL11A gene DNA methylation contributes to the risk of type 2 diabetes in males. Exp Ther Med 8: 459-463, 2014.

16. Tang L, Ye H, Hong Q, Wang L, Wang Q, Wang H, Xu L, Bu S, Zhang L, Cheng J, et al: Elevated $\mathrm{CpG}$ island methylation of GCK gene predicts the risk of type 2 diabetes in Chinese males. Gene 547: 329-333, 2014.

17. Weber M, Hellmann I, Stadler MB, Ramos L, Paabo S, Rebhan M and Schübeler D: Distribution, silencing potential and evolutionary impact of promoter DNA methylation in the human genome. Nat Genet 39: 457-466, 2007.

18. Dadke S, Kusari J and Chernoff J: Down-regulation of insulin signaling by protein-tyrosine phosphatase $1 \mathrm{~B}$ is mediated by an N-terminal binding region. J Biol Chem 275: 23642-23647, 2000.

19. Goldstein BJ, Bittner-Kowalczyk A, White MF and Harbeck M: Tyrosine dephosphorylation and deactivation of insulin receptor substrate-1 by protein-tyrosine phosphatase 1B. Possible facilitation by the formation of a ternary complex with the Grb2 adaptor protein. J Biol Chem 275: 4283-4289, 2000.

20. Zinker BA, Rondinone CM, Trevillyan JM, Gum RJ, Clampit JE, Waring JF, Xie N, Wilcox D, Jacobson P, Frost L, et al: PTP1B antisense oligonucleotide lowers PTP1B protein, normalizes blood glucose, and improves insulin sensitivity in diabetic mice. Proc Natl Acad Sci USA 99: 11357-11362, 2002. 
21. Cheng A, Uetani N, Simoncic PD, Chaubey VP, Lee-Loy A McGlade CJ, Kennedy BP and Tremblay ML: Attenuation of leptin action and regulation of obesity by protein tyrosine phosphatase 1B. Dev Cell 2: 497-503, 2002.

22. Zabolotny JM, Bence-Hanulec KK, Stricker-Krongrad A, Haj F, Wang Y, Minokoshi Y, Kim YB, Elmquist JK, Tartaglia LA, Kahn BB and Neel BG: PTP1B regulates leptin signal transduction in vivo. Dev Cell 2: 489-495, 2002.

23. Brown-Shimer S, Johnson KA, Lawrence JB, Johnson C Bruskin A, Green NR and Hill DE: Molecular cloning and chromosome mapping of the human gene encoding protein phosphotyrosyl phosphatase 1B. Proc Natl Acad Sci USA 87: 5148-5152, 1990

24. Elchebly M, Payette P, Michaliszyn E, Cromlish W, Collins S, Loy AL, Normandin D, Cheng A, Himms-Hagen J, Chan CC, et al: Increased insulin sensitivity and obesity resistance in mice lacking the protein tyrosine phosphatase-1B gene. Science 283: 1544-1548, 1999.

25. Klaman LD, Boss O, Peroni OD, Kim JK, Martino JL, Zabolotny JM, Moghal N, Lubkin M, Kim YB, Sharpe AH, et al: Increased energy expenditure, decreased adiposity, and tissue-specific insulin sensitivity in protein-tyrosine phosphatase 1B-deficient mice. Mol Cell Biol 20: 5479-5489, 2000.

26. Sun J, Wang Y, Fu X, Chen Y, Wang D, Li W, Xing S and Li G: Magnolia officinalis extract contains potent inhibitors against PTP1B and attenuates hyperglycemia in $\mathrm{db} / \mathrm{db}$ mice. Biomed Res Int 2015: 139451, 2015.

27. Maeda A, Kai K, Ishii M, Ishii T and Akagawa M: Safranal, a novel protein tyrosine phosphatase $1 \mathrm{~B}$ inhibitor, activates insulin signaling in $\mathrm{C} 2 \mathrm{C} 12$ myotubes and improves glucose tolerance in diabetic KK-Ay mice. Mol Nutr Food Res 58: 1177-1189, 2014.

28. Uddin MN, Sharma G, Yang JL, Choi HS, Lim SI, Kang KW and Oh WK: Oleanane triterpenes as protein tyrosine phosphatase 1B (PTP1B) inhibitors from Camellia japonica. Phy tochemistry 103: 99-106, 2014.

29. Alberti KG and Zimmet PZ: Definition, diagnosis and classification of diabetes mellitus and its complications. Part 1: Diagnosis and classification of diabetes mellitus provisional report of a WHO consultation. Diabet Med 15: 539-553, 1998

30. Zhou J, Huang Y, Huang RS, Wang F, Xu L, Le Y, Yang X, Xu W, Huang X, Lian J and Duan S: A case-control study provides evidence of association for a common SNP rs974819 in PDGFD to coronary heart disease and suggests a sex-dependent effect. Thromb Res 130: 602-606, 2012.

31. Tang LL, Liu Q, Bu SZ, Xu LT, Wang QW, Mai YF and Duan SW: The effect of environmental factors and DNA methylation on type 2 diabetes mellitus. Yi Chuan 35: 1143-1152, 2013 (In Chinese).

32. Bakke J and Haj FG: Protein-tyrosine phosphatase 1B substrates and metabolic regulation. Semin Cell Dev Biol 37: $58-65,2015$.

33. Chiarreotto-Ropelle EC, Pauli LS, Katashima CK, Pimentel GD Picardi PK, Silva VR, de Souza CT, Prada PO, Cintra DE, Carvalheira JB, et al: Acute exercise suppresses hypothalamic PTP1B protein level and improves insulin and leptin signaling in obese rats. Am J Physiol Endocrinol Metab 305: E649-E659, 2013.

34. Di Paola R, Frittitta L, Miscio G, Bozzali M, Baratta R, Centra M, Spampinato D, Santagati MG, Ercolino T, Cisternino C, et al: A variation in 3' UTR of hPTP1B increases specific gene expression and associates with insulin resistance. Am J Hum Genet 70 806-812, 2002

35. Bento JL, Palmer ND, Mychaleckyj JC, Lange LA, Langefeld CD, Rich SS, Freedman BI and Bowden DW: Association of protein tyrosine phosphatase 1B gene polymorphisms with type 2 diabetes. Diabetes 53: 3007-3012, 2004.
36. Murashov AK, Pak ES, Koury M, Ajmera A, Jeyakumar M, Parker M, Williams O, Ding J, Walters D and Neufer PD: Paternal long-term exercise programs offspring for low energy expenditure and increased risk for obesity in mice. FASEB J 30 775-784, 2016.

37. Keating ST and El-Osta A: Epigenetic changes in diabetes. Clin Genet 84: 1-10, 2013.

38. Sookoian S, Rosselli MS, Gemma C, Burgueño AL, Fernández Gianotti T, Castaño GO and Pirola CJ: Epigenetic regulation of insulin resistance in nonalcoholic fatty liver disease: Impact of liver methylation of the peroxisome proliferator-activated receptor $\gamma$ coactivator $1 \alpha$ promoter. Hepatology 52: 1992-2000, 2010.

39. Kuroda A, Rauch TA, Todorov I, Ku HT, Al-Abdullah IH, Kandeel F, Mullen Y, Pfeifer GP and Ferreri K: Insulin gene expression is regulated by DNA methylation. PLoS One 4: e6953, 2009.

40. Kamenov ZA, Parapunova RA and Georgieva RT: Earlier development of diabetic neuropathy in men than in women with type 2 diabetes mellitus. Gend Med 7: 600-615, 2010

41. Huxley R, Barzi F and Woodward M: Excess risk of fatal coronary heart disease associated with diabetes in men and women: Meta-analysis of 37 prospective cohort studies. BMJ 332: 73-78, 2006.

42. Zhang H and Sairam MR: Sex hormone imbalances and adipose tissue dysfunction impacting on metabolic syndrome; a paradigm for the discovery of novel adipokines. Horm Mol Biol Clin Investig 17: 89-97, 2014.

43. El-Maarri O, Becker T, Junen J, Manzoor SS, Diaz-Lacava A, Schwaab R, Wienker T and Oldenburg J: Gender specific differences in levels of DNA methylation at selected loci from human total blood: A tendency toward higher methylation levels in males. Hum Genet 122: 505-514, 2007.

44. Kaminsky Z, Wang SC and Petronis A: Complex disease, gender and epigenetics. Ann Med 38: 530-544, 2006.

45. Hall E, Volkov P, Dayeh T, Esguerra JL, Salö S, Eliasson L, Rönn T, Bacos K and Ling C: Sex differences in the genome-wide DNA methylation pattern and impact on gene expression, microRNA levels and insulin secretion in human pancreatic islets. Genome Biol 15: 522, 2014.

46. Fu Q, McKnight RA, Callaway CW, Yu X, Lane RH and Majnik AV: Intrauterine growth restriction disrupts developmental epigenetics around distal growth hormone response elements on the rat hepatic IGF-1 gene. FASEB J 29: 1176-1184, 2015.

47. Horvath S, Zhang Y, Langfelder P, Kahn RS, Boks MP, van Eijk K, van den Berg LH and Ophoff RA: Aging effects on DNA methylation modules in human brain and blood tissue. Genome Biol 13: R97, 2012.

48. Zykovich A, Hubbard A, Flynn JM, Tarnopolsky M, Fraga MF, Kerksick C, Ogborn D, MacNeil L, Mooney SD and Melov S: Genome-wide DNA methylation changes with age in disease-free human skeletal muscle. Aging Cell 13: 360-366, 2014.

49. Day K, Waite LL, Thalacker-Mercer A, West A, Bamman MM, Brooks JD, Myers RM and Absher D: Differential DNA methylation with age displays both common and dynamic features across human tissues that are influenced by $\mathrm{CpG}$ landscape. Genome Biol 14: R102, 2013.

50. Christensen BC,HousemanEA,MarsitCJ,Zheng S, Wrensch MR, Wiemels JL, Nelson HH, Karagas MR, Padbury JF and Bueno R: Aging and environmental exposures alter tissue-specific DNA methylation dependent upon CpG island context. PLoS Genet 5: e1000602, 2009.

51. Ling C, Poulsen P, Simonsson S, Rönn T, Holmkvist J, Almgren P, Hagert P, Nilsson E, Mabey AG, Nilsson P, et al: Genetic and epigenetic factors are associated with expression of respiratory chain component NDUFB6 in human skeletal muscle. J Clin Invest 117: 3427-3435, 2007. 